\title{
Hodgkin lymphoma: burden of the disease in Mexico. Construction of a proxy measure with administrative data of the National Health System
}

\author{
Silvia Rivas-Vera ${ }^{1 *}$, Ana Florencia Ramirez-Ibarguen ${ }^{1}$, Rhadames Figueroa-Acosta ${ }^{2}$ and \\ Yusimit de la Caridad Ledesma-Osorio² \\ ${ }^{1}$ Hematology Department, Instituto Nacional de Cancerologia, Ciudad de México; ${ }^{2}$ Medical Director, Takeda México SA de CV, Estado de México. \\ Mexico
}

\begin{abstract}
Introduction: While new therapies have increased survival for Hodgkin lymphoma (HL) in developed nations, the developing world still carries with most of the burden of this disease. Nevertheless, surveillance mechanisms for HL are lacking in Mexico. Methods: We developed a proxy for the burden of HL in Mexico using administrative data considering its prevalence, incidence, hospitalizations and mortality. The population consisted in individuals with International classification of diseases-10 code C81 attended in all Mexican institutions during 2016. The denominator of the rates was the age-specific population from census data. Structured interviews about treatment of HL were conducted with clinicians. Results: During 2016, 2,278 cases of HL were diagnosed; 3,241 patients were hospitalized and 535 died. The incidence rates of $H L$ were $32 \%$ higher in males versus females. Adults aged 60 years or older had the highest incidence rates of HL, followed by adults between 20 and 24 years old. The strategies to treat $H L$ were different between physicians working for the public and the private sector. Conclusion: The epidemiologic picture of HL in Mexico exhibits a pattern similar to that of developed countries. Our surrogate for the burden of HL will serve to plan and monitor future national cancer strategies.
\end{abstract}

Key words: Hodgkin lymphoma. Mexico. Burden. Epidemiology. Incidence rate.

\section{Introduction}

Although Hodgkin lymphoma $(\mathrm{HL})$ represents only $0.5 \%$ of global cancer burden, its prevalence is expected to increase as the population ages ${ }^{1}$. Survival of people with $\mathrm{HL}$ has increased as a result of recent therapeutic innovations ${ }^{2}$, with the epidemiological landscape of this disease having globally changed. However, therapeutic advances and access to care have not been equally distributed between countries with different stages of development. For example, $85.2 \%$ of patients with $\mathrm{HL}$ in Europe and $80.8 \%$ in the USA experience disease remission ${ }^{3,4}$, a positive trend that most developing countries have not shared. On the other hand, the majority of incident cases and deaths due to $\mathrm{HL}$ occur in developing countries. In fact, more than $10 \%$ of deaths and incident cases occur in Latin America $(\mathrm{LA})^{1}$, a region that lacks adequate epidemiological surveillance systems for non-communicable diseases. In addition, given that the treatment for $\mathrm{HL}$ changes drastically according to the stage and histologic subtype ${ }^{5}$, the need for surveillance mechanisms becomes even more imperious.

Previous measurements of the burden of $\mathrm{HL}$ in $\mathrm{LA}$ have faced several methodological challenges. Some countries, such as Mexico, do not have follow-up studies or cancer registries to directly consult $\mathrm{HL}$ incidence
Correspondence:

*Silvia Rivas-Vera

E-mail: silvia.rivasvera@gmail.com
Date of reception: 16-03-2019

Date of acceptance: 07-05-2019

DOI: 10.24875/j.gamo.M19000188
Available online: 05-11-2019 Gac Mex Oncol. 2019;19:1-6 www.gamo-smeo.com 1665-9201/@ 2019 Sociedad Mexicana de Oncología. Published by Permanyer México. This is an open access article under the terms of the CC BY-NC-ND license (http://creativecommons.org/licenses/by-nc-nd/4.0/). 
and mortality. Researchers have analyzed national data provided by the World Health Organization ${ }^{6}$; however, these data do not represent the complexity of the Mexican health system, characterized by fragmentation of the public sector and a significant presence of private actors ${ }^{7}$. In addition, Mexican health institutions provide care for people with different demographic and socioeconomic characteristics. Given that HL has unevenly-distributed risk factors between people with different demographic characteristics and socioeconomic status $^{8}$, the burden of $\mathrm{HL}$ could be expected to vary between different Mexican health institutions. Finally, current data sources do not include histological characterization or disease stage. Therefore, current estimates of the burden of $\mathrm{HL}$ in Mexico may be inaccurate and require adequate representation of the various institutions that provide medical care.

To estimate the burden of $\mathrm{HL}$ in Mexico, we consulted different data sources corresponding to private and public health systems and standardized them to represent the structure of the Mexican population. In addition, we conducted structured interviews with doctors with experience in the treatment of $\mathrm{HL}$ in Mexico to learn more about histological subtypes and stages in Mexican patients.

\section{Methodology}

To estimate the burden of $\mathrm{HL}$ in Mexico, we reviewed different data sources corresponding to private and public health systems for the year 2016. Inpatient and outpatient data were stratified by gender and age group ( $<15,15-19,20-24,25-29,30-49,50-59$ and $>60$ years).

$\mathrm{HL}$ cases were electronically identified or obtained by written request. Data sources included institutional yearbooks, institutional statistics reports, reports on morbidity and hospitalization statistics from the national health information system, and statistics from private institutions $^{9-13}$. Total number of deaths specifically related to LH was obtained from the General Directorate of Health Information ${ }^{14,15}$. Data on the population structure for each age group and gender projected to 2018 were obtained from the National Institute of Geography and Statistics (INEGI - Instituto Nacional de Geografía y Estadística $)^{16}$ and the National Population Council (CONAPO - Consejo Nacional de Población) ${ }^{17}$.

To obtain an approximation of the prevalence of $\mathrm{HL}$ in Mexico, we used a proxy variable, since there are no population-based epidemiological studies or patient records available. The International Classification of Diseases, $10^{\text {th }}$ revision (ICD-10), was used to identify people with HL. Our prevalence proxy was the total
Table 1. Hodgkin's lymphoma: incident cases, hospitalized patients and specific-cause deaths in Mexico, 2016

\begin{tabular}{|l|c|c|}
\hline & Women & Men \\
\hline $\begin{array}{l}\text { Absolute cases } \\
\text { Incident cases }\end{array}$ & 1,006 & \\
Hospitalized patients & 3,241 & \\
Hospitalizations & 3,986 & \\
Deaths & 535 & \\
\hline Rates & & \\
Incident cases & & \\
Hospitalized patients & \\
Hospitalizations $^{\ddagger}$ & 1.61 & 2.13 \\
Deaths $^{\S}$ & 2.65 & \\
\hline
\end{tabular}

*Patients attended to $\times 100,000$ population-year. ${ }^{\dagger}$ Hospitalized patients $\times 100,000$ population-year. ${ }^{\ddagger}$ Average hospitalizations per patient-year.

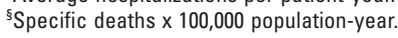

number of people with ICD-10 C81 code who were cared for during the 2016 period (full year) within the National Health System. Then, we divided the HL total number of cases in 2016 by the population corresponding to each age group/100,000 population, thus obtaining the prevalence rate per 100,000 persons-year. To obtain the age-specific mortality rate, we divided the number of $\mathrm{HL}$ deaths by the population in the age group/100,000 population. Our rationale for this analytical strategy is that through standardization we can compare our indicators with those of other health systems. Similarly, we calculated the HL incidence rate using the burden of disease methodology 6,18 .

To understand the clinical status and treatment of patients with $\mathrm{HL}$, we interviewed medical specialists following the Delphi methodology ${ }^{19}$. We designed an instrument to collect data from the review of the medical literature on $\mathrm{HL}$ available until 2018. We calculated the mean, standard deviation and $95 \%$ confidence intervals. Given the qualitative nature of this exercise, the sample size was not statistically significant.

The data collected using the Delphi panel reported the number of individuals with $\mathrm{HL}$ in a particular clinical status and on a specific treatment, as well as HL histological pattern and certain comorbidities.

\section{Results}

During 2016, 2,278 HL incident cases were diagnosed in the Mexican health system, which corresponds to an incidence rate of $1.93 / 100,000$ population. During that period, 3,241 patients with $\mathrm{HL}$ were hospitalized, with 1.23 hospitalizations per patient-year. A total of 535 patients with $\mathrm{HL}$ died in the course of 2016 (Table 1). 
Table 2. Hodgkin's lymphoma: incident cases and rates for men and women according to age groups in Mexico, 2016

\begin{tabular}{|c|c|c|c|c|c|c|c|c|}
\hline & \multicolumn{7}{|c|}{ Age group, years } & \multirow[t]{2}{*}{ Total } \\
\hline & $<15$ & $15-19$ & $20-24$ & $25-29$ & $30-49$ & $50-59$ & $\geq 60$ & \\
\hline $\begin{array}{l}\text { Women } \\
\text { Incident cases } \\
\text { Incident rates }\end{array}$ & $\begin{array}{c}93 \\
0.57\end{array}$ & $\begin{array}{c}54 \\
0.98\end{array}$ & $\begin{array}{c}148 \\
2.73\end{array}$ & $\begin{array}{c}80 \\
1.57\end{array}$ & $\begin{array}{c}194 \\
1.10\end{array}$ & $\begin{array}{c}87 \\
1.47\end{array}$ & $\begin{array}{l}350 \\
5.19\end{array}$ & $\begin{array}{r}1,006 \\
1.61\end{array}$ \\
\hline $\begin{array}{l}\text { Men } \\
\text { Incident cases } \\
\text { Incident rates }\end{array}$ & $\begin{array}{l}128 \\
0.81\end{array}$ & $\begin{array}{c}121 \\
2.15\end{array}$ & $\begin{array}{c}167 \\
3.14\end{array}$ & $\begin{array}{c}128 \\
2.68\end{array}$ & $\begin{array}{l}206 \\
1.30\end{array}$ & $\begin{array}{r}160 \\
3.03\end{array}$ & $\begin{array}{l}352 \\
6.09\end{array}$ & $\begin{array}{l}1272 \\
2.13\end{array}$ \\
\hline $\begin{array}{l}\text { Total } \\
\text { Incident cases } \\
\text { Incident rates }\end{array}$ & $\begin{array}{l}221 \\
0.69\end{array}$ & $\begin{array}{l}175 \\
1.57\end{array}$ & $\begin{array}{l}315 \\
2.93\end{array}$ & $\begin{array}{l}208 \\
2.10\end{array}$ & $\begin{array}{l}400 \\
1.20\end{array}$ & $\begin{array}{l}247 \\
2.21\end{array}$ & $\begin{array}{c}702 \\
5.61\end{array}$ & $\begin{array}{c}2,278 \\
1.93\end{array}$ \\
\hline
\end{tabular}

Table 3. Hodgkin's Iymphoma: prevalence according to histologic type, symptoms, treatment and viral comorbidity, 2016

\begin{tabular}{|c|c|c|c|c|c|c|c|}
\hline $\begin{array}{l}\text { Histologic } \\
\text { type }\end{array}$ & Nodular -sclerosing & $\begin{array}{l}\text { Mixed } \\
\text { cellularity }\end{array}$ & \multicolumn{2}{|c|}{$\begin{array}{l}\text { Nodular Iymphocyte } \\
\text { predominant }\end{array}$} & $\begin{array}{l}\text { Lymphocyte } \\
\text {-rich }\end{array}$ & Lymphocyte-depleted & Not specified \\
\hline Cases $(\%)$ & $766(33.6 \%)$ & $556(24.4 \%)$ & \multicolumn{2}{|c|}{$141(6.2 \%)$} & $129(5.7 \%)$ & $93(4.1 \%)$ & $553(26 \%)$ \\
\hline Symptoms & \multicolumn{3}{|c|}{ Paravertebral lymphadenopathy } & \multicolumn{2}{|c|}{ Fever } & Weight loss & Appetite loss \\
\hline Cases $(\%)$ & \multicolumn{3}{|c|}{$1,626(71.4 \%)$} & \multicolumn{2}{|c|}{$560(24.6 \%)$} & $378(16.6 \%)$ & $308(13.5 \%)$ \\
\hline Treatment & & \multicolumn{2}{|l|}{ Chemotherapy } & \multicolumn{2}{|c|}{ Radiotherapy } & \multicolumn{2}{|c|}{ Chemo and radiotherapy } \\
\hline Cases $(\%)$ & & \multicolumn{2}{|l|}{$1,760(77.3 \%)$} & \multicolumn{2}{|c|}{$207(9.1 \%)$} & \multicolumn{2}{|c|}{$311(13.6 \%)$} \\
\hline \multicolumn{2}{|c|}{ Virus-associated comorbidity* } & \multicolumn{3}{|c|}{ Epstein-Barr virus } & & \multicolumn{2}{|l|}{ Human herpesvirus 6} \\
\hline \multicolumn{2}{|l|}{ Cases (\%) } & \multicolumn{3}{|c|}{$1,508(66.2 \%)$} & & $378(16.6 \%)$ & \\
\hline
\end{tabular}

*Data estimated based on prevalence rates reported by the group of local experts.

HL incidence rates during 2016 were $32 \%$ higher in men than in women. Incidence rates had a bimodal distribution both in men and women; the highest were in people aged 60 years or older $(2.9$ times the overall average rate), followed by adults between 20 and 24 years ( 1.5 times the overall average rate). From 50 years of age on, an exponential growth was observed. Children younger than 15 years experienced the lowest $\mathrm{HL}$ incidence rates during the study period (Table 2).

Absolute number of patients with $\mathrm{HL}$ in the Mexican health system was 10,565 individuals during the study period. The most common histologic type was nodular-sclerosing, while lymphocyte-depleted was the least common. With regard to symptoms, most patients had lymphadenopathy, accompanied by fever, weight loss and appetite loss. More than $75 \%$ of patients received chemotherapy, while less than $10 \%$ only received radiotherapy (Table 3).
According to the interviewed treating physicians, the ABVD regimen (doxorubicin, bleomycin, vinblastine and dacarbazine) was the most widely used in the public sector for each $\mathrm{HL}$ stage. This regimen was less indicated in the private sector, except for stage IV patients. Biological treatment was used more often in the private sector at early stages of the disease, whereas in the public sector it was used at more advanced stages (Table 4).

The interviewed experts reported that a higher proportion of patients treated with second-line therapy died in the public sector in comparison with patients treated in the private sector. This trend was weaker for first-line treatment (Table 5).

\section{Discussion}

When patients come into contact with a health institution in Mexico, their diagnosis is recorded according 
Table 4. Hodgkin's lymphoma: systemic treatment with chemotherapy and/or biological therapy according to clinical stage and type of healthcare provider within the Health System, 2016

\begin{tabular}{|c|c|c|}
\hline & Public (\%) & Private (\%) \\
\hline $\begin{array}{l}\text { Stage I } \\
\text { ABVD (doxorubicin, bleomycin, vinblastine, dacarbazine) } \\
\text { CHOP (cyclophosphamide, doxorubicin, vincristine, prednisone) } \\
\text { Brentuximab } \\
\text { Nivolumab } \\
\text { PVAG (prednisone, vinblastine, doxorubicin, gemcitabine) }\end{array}$ & $\begin{array}{c}67.1 \\
32.9 \\
0 \\
0 \\
0\end{array}$ & $\begin{array}{c}24.1 \\
51.6 \\
23.6 \\
0 \\
0.7\end{array}$ \\
\hline $\begin{array}{l}\text { Stage II } \\
\text { ABVD } \\
\text { Stanford V } \\
\text { DHAP (dexamethasone, cisplatin, cytarabine) } \\
\text { Brentuximab } \\
\text { BEACOPP and escalated BEACOPP (doxorubicin, cyclophosphamide, etoposide, } \\
\text { procarbazine, prednisolone, bleomycin, vincristine, filgrastim) } \\
\text { PVAG } \\
\text { CHOP } \\
\text { Rituximab }\end{array}$ & $\begin{array}{c}69.3 \\
2.9 \\
7.9 \\
0 \\
0 \\
\\
4.4 \\
4.9 \\
10.7\end{array}$ & $\begin{array}{c}53.3 \\
23.4 \\
17.9 \\
4.7 \\
0.7 \\
\\
0 \\
0 \\
0\end{array}$ \\
\hline $\begin{array}{l}\text { Stage III } \\
\text { ABVD } \\
\text { BEACOPP and escalated BEACOPP } \\
\text { PVAG } \\
\text { DHAP } \\
\text { Nivolumab } \\
\text { Stanford V }\end{array}$ & $\begin{array}{c}85.6 \\
4.3 \\
4.0 \\
2.9 \\
3.3 \\
0.1\end{array}$ & $\begin{array}{c}73.3 \\
0 \\
0 \\
5.1 \\
0 \\
20.1\end{array}$ \\
\hline $\begin{array}{l}\text { Stage IV } \\
\text { ABVD } \\
\text { BEACOPP and escalated BEACOPP } \\
\text { Stanford V }\end{array}$ & $\begin{array}{c}74.7 \\
24.6 \\
0.7\end{array}$ & $\begin{array}{c}94.3 \\
5.7 \\
0\end{array}$ \\
\hline
\end{tabular}

Table 5. Hodgkin's lymphoma: patient characteristics according to their status with regard to treatment and type of healthcare provider within the Health System, 2016

\begin{tabular}{|l|c|c|}
\hline & Public (\%) & Private (\%) \\
\hline First-line & & \\
$\quad$ Eligible for treatment & 100 & 100 \\
Deceased & 7.9 & 8.6 \\
$\quad$ No progression & 75 & 73.3 \\
\hline Second-line & & \\
$\quad$ Eligible for treatment & 92.9 & 95.7 \\
Deceased & 23.6 & 15 \\
No progression & 52.1 & 85.7 \\
\hline
\end{tabular}

to ICD-10 codes for administrative purposes. Using these records, we constructed a proxy for prevalence and incidence rates. Our proxy was a useful tool to characterize the burden of $\mathrm{HL}$ in Mexico. This work represents the most complete and recent analysis of the prevalence, incidence and mortality of $\mathrm{HL}$ focusing on the region. We demonstrated that men were at higher risk than women. We also observed a bimodal incidence pattern, with higher incidence being found among elderly patients. Finally, treatment strategies and doctors' perceptions about clinical outcomes were different between those working in the public and private sectors.

The incidence rate we observed was 1.93 per 100,000 persons-year. Previous research conducted in a Mexican population reported an incidence rate of 1.4 per 100,000 persons-year ${ }^{6}$, which contrasts with our results. However, coinciding with our findings, another study found an incidence rate of 1.8 per 100,000 persons-year in Mexico ${ }^{19}$. This discrepancy may be due to methodological reasons, since the second referred study and ours used a more comprehensive set of data sources, while the first one used a single cancer registry. Studies in Hispanic populations, in countries with more comprehensive cancer registries, are another useful comparison. For example, the researchers found higher incidence rates among Hispanics in comparison with our population. However, in USA, the incidence rate decreased for Hispanics who were born there ${ }^{20}$.

When we stratified the incidence rates by age, we found a bimodal pattern with an initial peak slightly higher than $50 \%$ of the mean overall rate in the 20 - to 
24-year-old age group, followed by an exponential increase starting at 50 years of age, up to a second peak markedly higher than the first one (almost 200\% higher than the overall average) in the group of 60 -yearold or older subjects. This pattern, together with a predominant histologic variety of the nodular sclerosing type, is known as the "third pattern" that is described in developed countries ${ }^{6}$. This trend was not observed in a population of individuals of Hispanic descent in the $\mathrm{USA}^{20}$, where only a small relative increase in the incidence rate corresponded to the 20- to 24-year-old age group. However, the exponential growth pattern observed in the incidence of $\mathrm{HL}$ starting at 50 years of age is similar to that found by other researchers who studied populations in South and Central America ${ }^{6}$. Although children were the group with the lowest $\mathrm{HL}$ incidence rates, these were higher than those found in previous studies ${ }^{21}$. However, the rates in Mexico were significantly higher in comparison with those in highly industrialized nations in the age group of subjects younger than 10 years. This is particularly observed in the south of the country, where the socioeconomic level is lower than the national average, according to recent reports ${ }^{21}$.

As an explanation for this observation regarding the report of higher $\mathrm{HL}$ incidence rates in children of developing countries, Chabay and Preciado postulate the fact that Epstein-Barr virus (EBV) infection occurs in this nations at earlier stages of life ${ }^{22}$. This statement correlates with data reported in Mexico in the timeline of the disease (1995 by Zárate and 2004 by Romero), where $64-70 \%$ of children with $\mathrm{HL}$ were positive for EBV, in contrast with $50 \%$ in developed countries ${ }^{23-25}$. However, given that these local studies were carried out 15 or more years ago, the prevalence of EBV infections may have changed during all these years. Hence, current features of this epidemiological singularity of $\mathrm{HL}$ in children should be studied more deeply.

The male: female ratio we observed for the incidence of $\mathrm{HL}$ was 1.32. Our study was consistent in magnitude and direction with previous results ${ }^{6}$. Similarly, the male gender was associated with a higher incidence of $\mathrm{HL}$ among Hispanics living in USA, but the association was stronger than that observed by $u^{20}$. This pattern was present even for subjects younger than 15 years. However, the association we found was weaker for this age group, in contrast to other researchers who found an incidence rate ratio of $2.5^{21}$.

The mortality rate we observed for $\mathrm{HL}$ was 0.44 per 100,000 persons-year. This finding is consistent with previous research on $\mathrm{HL}$ in Mexico, where it was estimated at $0.48^{6}$. However, other researchers reported a specific mortality rate of 0.7 for the 1990-2013 period $^{19}$. The authors also found a decrease in mortality rates during that period, which might explain the lower mortality rates herein presented. The survival increase might reflect the higher prevalence of older people treated for $\mathrm{LH}^{3}$. These people have an increased risk of cardiovascular disease and second malignancies and, therefore, should be carefully monitored ${ }^{26}$.

When we interviewed doctors with experience in the treatment of $\mathrm{HL}$, their answers varied according to the type of institution they worked at. The treatment patterns we found might reflect the characteristics of the population under study. For example, the US National Comprehensive Cancer Network guidelines recommend, among other resources, the use of cyclophosphamide, doxorubicin, vincristine and prednisone (CHOP), or prednisone, vinblastine, doxorubicin and gemcitabine (PVAG) in patients older than 60 years ${ }^{27}$. The differences in access to therapeutics between public and private institutions (Essential Medicines List and Health Sector Supplies Catalog) might explain the differences in our findings (Table 4). In addition, it is important to consider that biological drugs were available for therapy in the private sector before than in the public sector. The group of interviewed treating physicians considered that even the higher relative use of these therapeutics is related to this fact. Either way, it is important bearing in mind that treatment information in this study is qualitative.

The main strength of our study was the comprehensive set of data sources represented by the different branches of the Mexican health system. However, it has the limitations intrinsic to the use of administrative databases, particularly regarding the lack of clinical and socioeconomic variables. In contrast, administrative databases have many inherent advantages (such as systematization, code list uniformity, periodicity, etc.) that position them as a highly useful resource, particularly in settings with low access to reliable and systematic information, as it is the case of Mexico. Although our prevalence proxy does not replace other designs, it is less expensive and more convenient than prospective follow-up studies. Future designs, carried out in settings where electronic health records are available, might include this data and detailed treatment information. In addition, the assessment of incidence and mortality trends by State might give clues on the quality and provision of health resources.

Our results provide the most accurate estimates of the HL load in Mexico. However, as the population and 
life expectancy increase, $\mathrm{HL}$ will be more prevalent. In addition, $\mathrm{HL}$ survivors have an increased risk of death due to different causes. Therefore, improving $\mathrm{HL}$ surveillance would allow planning, monitoring and evaluating future interventions and should be a goal for a national strategy against cancer.

\section{Acknowledgements}

We thank Links \& Links for the support in the performance of this research, as well as for assistance in the writing of this document, both activities funded by Takeda México SA de CV.

\section{Funding}

This study was sponsored by Takeda México SA de CV.

\section{Conflict of interests}

The present study was funded by Takeda México SA de $C V$, without this having generated any type of responsibility of legal nature and/or related to the results.

Dr. Silvia Rivas was Head of the Hematology Department of the National Cancerology Institute of Mexico during the time of the study.

Dr. Ana Florencia had participated as part of the Takeda México SA de CV speakers' bureau and had received travel support from Takeda México SA de CV.

Rhadames Figueroa-Acosta was an employee of Takeda México SA de CV during the study.

Yusimit de la Caridad Ledesma-Osorio was an employee of Takeda México SA de CV during the study.

\section{References}

1. Ferlay J, Soerjomataram I, Dikshit R, Eser S, Mathers C, Rebelo M, et al. Cancer incidence and mortality worldwide: Sources, methods and major patterns in GLOBOCAN 2012. Int J Cancer. 2015;136(5):E359-86.

2. Chatenoud L, Bertuccio $P$, Bosetti C, Rodriguez T, Levi F, Negri E, et al. Hodgkin's lymphoma mortality in the Americas, 1997-2008: Achievements and persistent inadequacies. Int J Cancer. 2013;133(3):687-94.

3. Brenner H, Gondos A, Pulte D. Ongoing improvement in long-term survival of patients with Hodgkin disease at all ages and recent catch-up of older patients. Blood. 2008;111(6):2977-83.

4. Storm HH, Klint A, Tryggvadóttir L, Gislum M, Engholm G, Bray F, et al. Trends in the survival of patients diagnosed with malignant neoplasms of lymphoid, haematopoietic, and related tissue in the Nordic countries 1964-2003 followed up to the end of 2006. Acta Oncol. 2010;49(5):694-712.

5. Ansell SM. Hodgkin lymphoma: Diagnosis and treatment. Mayo Clin Proc. 2015;90(11):1574-83.
6. Kusminsky G, Abriata G, Forman D, Sierra MS. Hodgkin lymphoma burden in Central and South America. Cancer Epidemiol. 2016;44(Suppl 1):S158-67.

7. Gómez-Dantés O, Sesma S, Becerril V, Knaul F, Arreola H, Frenk J. Sistema de salud de México. Salud Publica Mex. 2011;53(Supl 2): S220-S232.

8. Maggioncalda A, Malik N, Shenoy P, Smith M, Sinha R, Flowers CR. Clinical, molecular, and environmental risk factors for Hodgkin lymphoma. Adv Hematol. 2011;2011:736261.

9. Datos Abiertos - Anuarios Estadísticos de Morbilidad [Internet]. México: Secretaría de Salud, Dirección General de Epidemiología [fecha de publicación: 22 de marzo de 2018]. Disponible en: https://www.gob.mx/ salud/documentos/datos-abiertos-152127.

10. Plataforma Nacional de Transparencia. Sistema INFOMEX. Solicitud de Información pública [Internet]. México: Instituto Nacional de Transparencia, Acceso a la Información y Protección de Datos Personales. Disponible en: https://www.infomex.org.mx/gobiernofederal/home.action.

11. Instituto Nacional de Estadística y Geografía de México. Proyectos Estadísticos. Salud en Establecimientos Particulares (1994-2015). Disponible en: https://www.inegi.org.mx/programas/salud

12. Anuarios Estadísticos del Instituto de Seguridad y Servicios Sociales de los Trabajadores del Estado. 2015 [Internet]. México: Gobierno de México [fecha de consulta: 31 de agosto de 2018]. Disponible en: https:// www.gob.mx/issste/documentos/anuarios-estadisticos

13. Anuarios estadísticos IMSS (2000-2015) [Internet]. México: INEGI. Disponible en: http://datos.imss.gob.mx/dataset

14. Cubos Dinámicos-Defunciones (Mortalidad). Defunciones cifras oficiales definitivas. 1979 - 2016 [Internet]. México: Gobierno de México, Dirección General de Información de Salud [fecha de consulta: 31 de agosto de 2018]. Disponible en: http://www.dgis.salud.gob.mx/contenidos/basesdedatos/bdc defunciones gobmx.html

15. Secretaría de Salud. Cubos Dinámicos-Egresos Hospitalarios. Defunciones cifras oficiales definitivas. 2000 - 2016. [Internet]. México: Gobierno de México, Dirección General de Información de Salud [fecha de consulta: 31 de agosto de 2018]. Disponible en: http://www.dgis.salud.gob.mx/ contenidos/basesdedatos/bdc_egresoshosp_gobmx.html

16. Censo de Población y Vivienda 2010 [Internet]. México: Instituto Nacional de Estadística y Geografía; 2013. Diponible en: https://www.inegi.org.mx/ programas/ccpv/2010

17. Proyecciones poblacionales por grupo de edad y sexo. $2010-2050$ [Internet]. México: Secretaría de Gobernación, Consejo Nacional de Población, Acciones y Programas. Disponible en: https://www.gob.mx/ conapo/acciones-y-programas/conciliacion-demografica-de-mexico-1950-2015-y-proyecciones-de-la-poblacion-de-mexico-y-de-las-entidades-federativas-2016-2050

18. Murray CJ, Ezzati M, Flaxman AD, et al. GBD 2010: Design, definitions and metrics. The Lancet. 2012;380(9859):2063-6.

19. Gómez-Dantés, H. et al. The burden of cancer in Mexico, 1990-2013. Salud Publica Mex. (2016). doi:10.21149/spm.v58i2.7780

20. Evens AM, Antillón M, Aschebrook-Kilfoy B, Chiu BCH. Racial disparities in Hodgkin's lymphoma: A comprehensive population-based analysis. Ann Oncol. (2012). doi:10.1093/annonc/mdr578

21. Rendon-Macias ME, Valencia-Ramon EA, Fajardo-Gutierrez A, Castro-Rios A. Incidence of childhood hodgkin lymphoma in Mexico by histologic subtypes and socioeconomic regions. J Pediatr Hematol Oncol. (2016). doi:10.1097/MPH.0000000000000462

22. Chabay PA, Preciado MV. EBV primary infection in childhood and its relation to B-cell lymphoma development: A mini-review from a developing region. International Journal of Cancer (2013). doi:10.1002/ijc.27858

23. Zarate-Osorno A, Roman LN, Kingma DW, Meneses-Garcia A, Jaffe ES Hodgkin's disease in Mexico. Prevalence of Epstein-Barr virus sequences and correlations with histologic subtype. Cancer. (1995). doi:10.100 2/1097-0142(19950315)75:6<1360:AID-CNCR2820750619>3.0.CO;2-U

24. Glaser, S. L. et al. Hodgkin lymphoma incidence in California Hispanics: Influence of nativity and tumor Epstein-Barr virus. Cancer Causes Control (2014). doi:10.1007/s10552-014-0374-6

25. Romero $\mathrm{M}$, Cruz H, Huetter M. Prevalencia de virus herpes humanos en linfoma de Hodgkin. Rev Med Hosp Gen Mex. 2004;67(3):124-9.

26. Darrington DL, Vose JM. Appropriate surveillance for late complications in patients in remission from hodgkin lymphoma. Current Hematologic Malignancy Reports (2012). doi:10.1007/s11899-012-0128-z

27. Colevas, A. D. et al. NCCN guidelines ${ }^{\circledR}$ insights: Head and neck cancers, version 1.2018 featured updates to the NCCN guidelines. JNCCN Journal of the National Comprehensive Cancer Network (2018). doi:10.6004/ jnccn.2018.0026 